総 説

\title{
日本列島に生息する野ネズミ類から検出された 寄生線虫の生物地理学
}

\author{
浅川 満彦 \\ 酪農学園大学獣医学部寄生虫学教室 $\overline{\mathbf{T}} 069$ 北海道江別市文京台緑町 582 の 1
}

\section{Zoogeography on parasitic nematodes of wild murids from Japanese Archipelago}

\author{
Mitsuhiko ASAKAWA
}

Laboratory of Parasitology, Department of Veterinary Medicine, Rakuno Gakuen University, Ebetsu, Hokkaido, 069 Japan

\begin{abstract}
As part of a zoogeographical research project, an analysis was made on the parasitic nematode fauna of the Japanese Microtinae and Murinae (Mammalia: Rodentia: Muridae). A total of 36 nematode species (16 families and 24 genera) were recognized from the host genera Clethrionomys, Eothenomys, Microtus and Apodemus on the Japanese archipelago. Among the parasitic nematodes, the zoogeographical analyses of the nematode genus Heligmosomoides (Heligmosomidae: Strongylida) were made with regard to the speciation and geographical distribution of the nematodes, the fossil records of small mammals and the geological record of the archipelago.
\end{abstract}

Key words: Clethrionomys, Eothenomys Microtus, Apodemus, Heligmosomoides

Jpn.J.Zoo Wild.Med. 2(1) : 35-44, 1997

「どのような問題の解明のために, どのような材料を選ぶ のかということは科学的，少なくとも意識的になされなけ ればならない」とする白上 [1] の主張は，野生動物医学の 研究を行う上でも同様である。ところで，野生動物を対象 としなければ，展開できない研究領域の一つに生物地理学 がある。生物地理学には，対象とする生物種が特定地域に 自然分布古るに到った歴史的経緯を説明する使命がある。 したがって, 生物地理学的研究の材料は, 原則として自然 分布した種で，家畜や帰化動物など獣医学で中心となる動 物が扱われることは少ない。このような理由から，生物地 理学と獣医学との接点はほとんどなかったが, 獣医学が環 境科学としての側面を持ちつつある今日，生物地理学と疎 遠であってはならない。

生物地理学は自由生活する生物をもとに発展した学問体
系ではあるが，寄生虫においてもそれが自然分布した種な

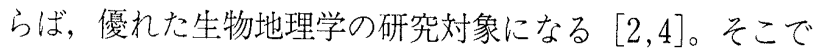
この論文では, まず日本列島産野ネズミ類に寄生する線虫 類の生物地理学的研究をモデルとして取り上げる。これに よって，野生動物を扱う獣医師が生物地理学的視点を持つ 意義について考えたい。

\section{寄生線虫の分布調査}

日本列島には，ネズミ巠科 Murinae と八タネズミ巠科 Microtinae のネズミ科動物 Muridae が自然分布してい る。これらは一般に野ネズミ類と称され，我々が家屋で目 にするドブネズミなどの住家性ネズミ類とは明確に区別さ れる。野ネズミ類のうち，八タネズミ巠科は草や樹皮を好 む草食動物であり，主な生活空間は半地下性である。一方， 
ネズミ亜科の方は植物性の果実のほか, 節足動物なども捕 食する雑食性であり，木登りが巧みで三次元的空間に適応 した動物である。しかし，いずれの野ネズミ類も住家性ネ ズミ類とは異なり, 人為的移動が少なく, 採集が容易で, 加 えて分類や系統の研究の蓄積があるなどの生物地理学の研 究に都合の良い性質がある。

おそらく, 宿主特異性の高い寄生線虫類についても, 優 れた生物地理学の研究対象となることが予想された。とこ ろが，どこの，どの種の野ネズミ類にどのような寄生線虫 類がいるのかといった基礎的な情報はまったく不足してい た。そこで, 浅川 [5] は日本列島全域(図 1)で採集した野 ネズミ類を寄生虫学的に検索した。用いた野ネズミ類は，い ずれも日本列島でありふれた種で，エゾヤチネズミClethrionomys rufocanus bedfordiae, ミカドネズミC. rutilus mikado，ムクゲネズミC． rex，ヤチネズミEothenomys andersoni, スミスネズミE. smithii, 八夕ネズミMi-

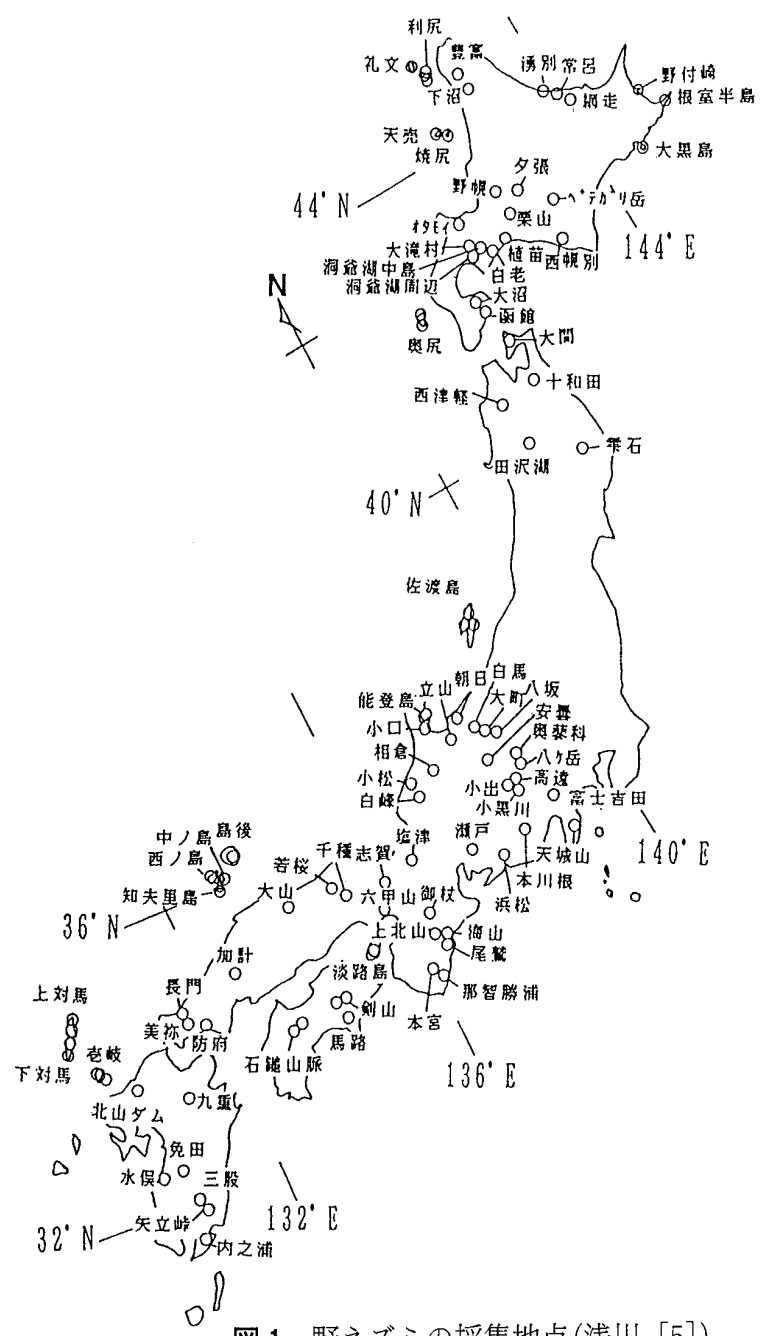

図 1 野ネズミの採集地点(浅川 [5]) crotus montebelli, アカネズミApodemus speciosus, ヒメ ネズミA. argenteus およびハントウアカネズミA. peninsulaeの 9 種, 合計 3,113 個体であった。これら野ネ ズミ類のうち，エゾヤチネズミ，ミカドネズミおよびムク ゲネズミが八タネズミ亜科のヤチネズミ属 Clethrionomys に，またヤチネズミとスミスネズミが同亜科ビロードネズ ミ属Eothenomysに，コらにハタネズミが同亜科八タネズ ミ属Microtusにそれぞれ所属している。一方，アカネズ ミ，ヒメネズミおよU゙ハントウアカネズミはいずれもネズ ミ亜科アカネズミ属 Apodemus に所属している。

これらのネズミから, 13 科, 21 属, 32 種の寄生線虫類(表 1)が検出された。これらの多くが，我々の一連の研究で明 らかにされた新種, 日本初あるいは新宿主の記録などの新 知見に属すものであった。また，これらの線虫がいかに複 雑で多様性に富んだ生物か，その生活史に着目するだけで 理解できる(図 2)。

これら以外に, ヒメネズミから糞線虫科 Strongyloides sp.が，またハタネズミから開嘴虫科 Syngamus sp.が報告

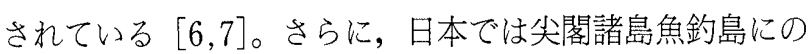
み分布するセスジネズミApodemus agrariusから, 最近, ヘリグモネラ科Heligmonoides sp.と胞翼虫科 Physaloptera sp.が発見された [8]。しかし，いずれの種も 我々の調査では未発見であった。なお，今回の調查でネズ ミ亜科のカヤネズミMicromys minutus が 1 個体採集さ れたが, 線虫類は未発見であった。また, 琉球列島産ネズ ミ亜科のトゲネズミTokudaia osimensis，ケナガネズミ Diplothrix legatus 㧍よびオキナワハツカネズミMus caroli の寄生虫については，すでに長谷川 [9] が論じている ので，あらためて調査の対象とはしなかった。日本列島に 分布するネズミ科動物には，この他，ネズミ亜科に所属す るドブネズミRattus norvegicus, クマネズミ Rattus rattus およびハツカネズミMus musculus の住家性ネズミ類と八 タネズミ亜科比所属する移入種マスクラットOndatra zibethicus が生息する。しかし, これらはなんらかの人為的 要因により日本列島に侵入・分布を遂げた動物群であり, 生 物地理学的検討にはあまり適当ではないと判断され，我々 の研究対象とはしなかった。

\section{分布の類型化}

ところで, この多様な寄生線虫類は, 日本列島内でどの 


\section{野ネズミ類から検出された寄生線虫の生物地理}

表 1 琉球列島を除く日本に自然分布したネズミ科動物で報告された寄生線虫類(浅川 [5] 一部改変)

\begin{tabular}{|c|c|c|c|}
\hline 寄生虫 & 宿 主 & 寄生虫 & 宿 主 \\
\hline ヘリグモソームム科 & & S. petrusewiczii & $\mathrm{Cm}$ \\
\hline Heligmosomum $(P$.$) yamagutii$ & $\mathrm{Cb}, \mathrm{Cr},(\mathrm{Cm}),(\mathrm{Aa})$ & 盲腸虫科 & \\
\hline$H .(P$.$) mixtum$ & $\mathrm{Cm}$ & Heterakis spumosa & $\mathrm{Cb}, \mathrm{Ea}, \mathrm{Es}, \mathrm{Mm}, \mathrm{As}, \mathrm{Aa}$, \\
\hline H. (P.) hasegawai & $\mathrm{Ea}, \mathrm{Es}$ & & $\mathrm{Ap}$ \\
\hline$H .(H$.$) halli$ & $\mathrm{Mm}$ & スブルラ科 & \\
\hline Heligmosomoides protobullosus & $\mathrm{Mm}$ & Subulura (M.) suzukii & $\mathrm{As}, \mathrm{Aa}$ \\
\hline H. kurilensis & $\mathrm{As},(\mathrm{Aa}),(\mathrm{Ap}),(\mathrm{Cb})$ & リクチュラリア科 & \\
\hline H. desportesi & $\mathrm{Aa},(\mathrm{As}),(\mathrm{Ap})$ & Rictularia cristata & $\mathrm{As}, \mathrm{Aa}, \mathrm{Ap}$ \\
\hline H. neopolygyrus & $\mathrm{Ap}$ & 旋尾虫科 & \\
\hline $\begin{array}{l}\text { H. polygyrus } \\
\text { ヘリグモネラ科 }\end{array}$ & (Aa) & $\begin{array}{l}\text { Mastophorus muris } \\
\text { 胞翼虫科 }\end{array}$ & Es, Mm, As, Aa \\
\hline Heligmonoides speciosus & $\mathrm{As}, \mathrm{Aa},(\mathrm{Ap}),(\mathrm{Cb})$ & Physaloptera sp. ${ }^{* 1}$ & Aag \\
\hline Heligmonoides sp. ${ }^{* 1}$ & Aag & ゴンギロネマ科 & \\
\hline Mammanidula hokkaidensis & $\mathrm{Cb}, \mathrm{Cm}, \mathrm{Cr}, \mathrm{As}, \mathrm{Aa}$ & Gongylonema $(G$.$) neoplasticum$ & $\mathrm{Es}, \mathrm{As}, \mathrm{Aa}$ \\
\hline Yatinema japonicum & $\mathrm{Es}, \mathrm{Ea}$ & 桿線虫科 & \\
\hline Morganiella cricetuli ${ }^{* 2}$ & Es あるいは (Es) & Rhabditis (P.) orbitalis & $\mathrm{Cb}, \mathrm{Cr}, \mathrm{Cm}, \mathrm{Es}, \mathrm{Mm}, \mathrm{As}$, \\
\hline $\begin{array}{l}\text { Carolinensis minutus } \\
\text { 毛様線虫科 }\end{array}$ & $\mathrm{Mm}$ & 䔬線虫科 & $\mathrm{Aa}$ \\
\hline $\begin{array}{l}\text { Trichostrongylus retortaeformis } \\
\text { 開嘴虫科 }\end{array}$ & $\mathrm{Mm}$ & $\begin{array}{l}\text { Strongyloides sp. }{ }^{* 1} \\
\text { オンコセルカ科 }\end{array}$ & $\mathrm{Aa}$ \\
\hline $\begin{array}{l}\text { Syngamus sp. }{ }^{* 1} \\
\text { 蟯虫科 }\end{array}$ & $\mathrm{Mm}$ & $\begin{array}{l}\text { Onchocercidae gen sp. } \\
\text { 毛細線虫科 }\end{array}$ & $\mathrm{As}, \mathrm{Aa}$ \\
\hline Syphacia agraria & $\begin{array}{l}\mathrm{Ap}, \mathrm{As} \text { あるいは(As), } \mathrm{Aa} \\
\text { あるいは(Aa) }\end{array}$ & $\begin{array}{l}\text { Aonchotheca murissylvatici } \\
\text { Eucoleus sp. }\end{array}$ & $\begin{array}{l}\mathrm{Cb}, \mathrm{Cr}, \mathrm{Ea}, \mathrm{Aa} \\
\mathrm{As}, \mathrm{Aa} \text { あるいは (Aa) }\end{array}$ \\
\hline S. emileromani & $\mathrm{Aa},(\mathrm{As}),(\mathrm{Ap})$ & Calodium hepaticum & $\mathrm{Cb}, \mathrm{Cm}, \mathrm{Aa}$ \\
\hline S. frederici & As, (Aa) & Pseudocapillaria $\mathrm{sp.}$ & Aa \\
\hline S. montana & $\begin{array}{l}\mathrm{Cb}, \mathrm{Cm} \text { あるいは }(\mathrm{Cm}), \mathrm{Cr}, \\
\mathrm{Ea}, \mathrm{Es}, \mathrm{Mm}\end{array}$ & $\begin{array}{l}\text { 鞭虫科 } \\
\text { Trichuris sp. }\end{array}$ & $\mathrm{Cb}, \mathrm{Cm}, \mathrm{Mm}$ \\
\hline
\end{tabular}

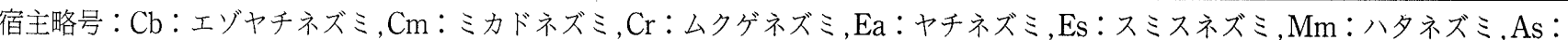
アカネズミ,Aa：ヒネネズミ,Aag：セスジネズミ,Ap：ハントウアカネズミ

()：当該宿主では偶発的な寄生と考えられたもの。

*1これらは，王ら [7]，高尾ら [6]，Hasegawa ら [8] の報告した種である(本文参照)。

${ }^{* 2}$ Morganiella 属は別属に編入されているが, 分類学上の問題が末解決の部分も残されているので, 今回は種名 Morganiella cricetuli 用いた。

ような地理的分布のパターンを示すのだろうか。ここでは 日本列島を北海道，本州，四国，九州の本島と島に分けて 概観するが，ここでは誌面の都合上，野ネズミ類に宿主特 異的に寄生するへリグモソームム科線虫 9 種に限って考察 する。なお，ここで述べるへリグモソームム科は，いずれ も第 4 期幼虫と成虫は野ネズミの小腸に寄生し，第 1 から 3 期幼虫は外界で自由生活をする。感染は, 第 3 期幼虫が経 口的に取り込まれることによって起こる(図 2 最上段)。成 虫の体長は約 $10 \mathrm{~mm}$, 虫体はコイル状を呈し，生きている 時は赤色で, 非常に美しい小型の線虫である。獣医学領域
では，反莓家畜の第四胃に寄生するネンテンイチュウやオ ステルダーグイチュウなどに系統的に近く，外見も似てい る。

住家性ハツカネズミに寄生し，人為的に日本列島に分布 するようになった Heligmosomoides polygyrus (Dujardin) を除くと，ヘリグモソームム科 8 種の地理的分布の様式は 次のようになる。(1)北海道・本州・四国・九州の本島扔よ び国後島・佐渡島・壱岐などの島に分布する種は Helig. mosomoides kurilensis (Nadtochi), (2)北海道・本州・四国・ 九州の本島に分布する種は $H$. desportesi (Chabaud et 


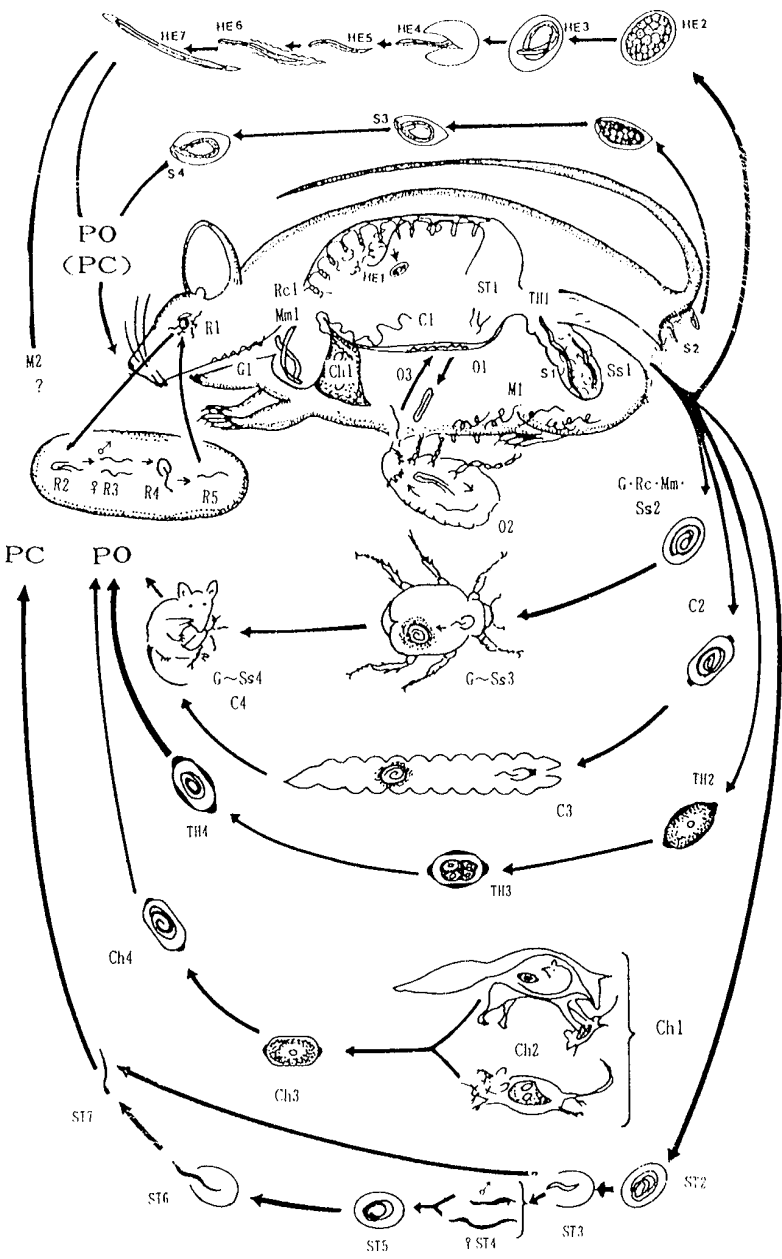

図 2 野ネズミ類寄生線虫の生活史概略

(浅川 [5] を一部改変)

HE 1-7：ヘリグモソームム科およびへリグモネラ科(ただ し Mammanidula 属は除く)の成虫は小腸に寄生し(1)，虫 卵は粪と一緒に外界へ出る (2)。幼虫が土壌上で自由生活し (3-6)，感染幼虫が経口 $(\mathrm{PO})$ あるいは経皮 $(\mathrm{PC})$ 感染する (7)。開嘴虫科の成虫は気管に寄生するが，生活史はこれら にほぼ準ずる。ただし，卵内で 3 期幼虫まで発育すること，
時に含幼虫卵の経口感染か待機宿主(ミミズなど)を介した感染様式をと ることで若干の差異がある。

M 1 と 2: Mammanidula 属の成虫は乳腺あるいは尿道球腺に寄生し (1), その後の発育は他のへリグモネラ科同様と予想されるが, 感染様式 は不明である $(2)$ 。

S 1-4：蟯虫科の成虫は查腸に寄生し(1)，虫卵は肛門周囲に産みつけら れる(2)。虫卵内に感染幼虫が形成され経口感染する(3 と 4 )。

R 1-5：桿線虫科 Rhabditis (Pelodera) orbitalis の第 3 期幼虫は眼球周 团組織に寄生し(1), 土㙋上で第 4 期から成虫となり交尾し(2 と 3), 虫卵 を産出，第 1 および 2 期幼虫が形成される(4と5)。

0 1-3：オンコセルカ科の成虫は消化管粘膜下組織に奇生し, 第 1 期幼虫 を産出(1), 体液中の幼虫がノミなどの中間宿主に取り込まれ，感染幼虫 にまで発育する(2)。その感染幼虫がノミにより新しい宿主に伝播(様式 は経皮感染)される(3)。

$\mathrm{G} \cdot \mathrm{Rc} \cdot \mathrm{Mm} \cdot \mathrm{Ss} 1-4$ ：ゴンギロネマ科 $(\mathrm{G})$ は食道粘膜に，リクチュラリ ア科 $(\mathrm{Rc})$ と旋尾虫科 $(\mathrm{Mm})$ は胃に，スブルラ科 $(\mathrm{Ss})$ は盲・結腸にそれぞ れ成虫が寄生し (1)，虫卵は糞と一緒に外界へ出る (2)。その虫卵は昆虫な どの中間宿主に取り込まれ, 感染幼虫にまで発育する(3)。この中間宿主 が慨として摂取され, 経口的に感染が成立する(4)。胞翼虫科成虫は胃に 寄生し，生活史は以上に準ずる。

C 1-4：毛細線虫科(ただしCalodium 属は除く)の成虫は胃あるいは小 腸に寄生し (1), 虫卵は䔬と一緒に外界へ出る(2)。それら虫卵はミミズな どの中間宿主に取り込まれ, 感染幼虫にまで発育する (3)。その中間宿主 を野ネズミ類が慨として摂取し，経口的に感染が成立する(4)。

TH 1-4：鞭虫科抢よび盲腸虫科の成虫は盲・結腸に寄生し(1), 虫卵は䔬 と一緒に外界へ出る (2)。虫卵内に感染幼虫が形成され経口感染する (3 と 4)。

Ch 1-4：Calodium 属の成虫は肝臟に寄生し(1), 虫卵は野ネズミが捕食 や共食いされるか死亡するなどにより体が分解された後, 外界へ出るこ とができる $(2$ と 3$)$ 。そして虫卵内に感染幼虫が形成され新たな宿主に経 口感染する $(3$ と 4$)$ 。

ST 1-7：糞線虫科 Strongyloides 属の成虫(寄生世代雌) は小腸に寄生し (1), 虫卵は資と一緒に外界へ出る (2)。土壌上で第 3 から 4 期幼虫を経て 自由生活世代の雌雄成虫に成長し交尾(3 から 4$)$, 虫卵を産出する (5)。そ の虫卵から第 1 から 2 期幼虫, そして感染幼虫が形成され, 新たな宿主に 経皮感染する(6と7)。しかし温度・湿度などの環境条件によっては, こ のような自由生活世代の成虫にならず，感染が成立する $(3 \rightarrow 7)$ 。 $a l$.), (3)本州・四国・九州の本島に分布する種は Heligmosomum (Paraheligmosomum) hasegawai Asakawa, (4) 本州本島抢よび能登島に分布する種は Heligmosomoides protobullosus Asakawa et Ohbayashi, (5)本州の本島に分 布する種はHeligmosomum (H.) halli Schulz, (6)北海道 本島およびその周辺の大黒島・天売島などの島に分布する 種は $H$. (P.) yamagutii (Chabaud et al.), (7)北海道本島 にのみ分布する種はH.(P.) mixtum Schulz および Heligmosomoides neopolygyrus Asakawa et Ohbayashi
である。

次に述べる日本列島の地史を基に，これら(1)〜 (7)の分布 記録を類型化すると,(1)と(2)の種群(「全日本グループ」と称 する), (3)〜 (5)の種群 (「本州陸塊 (後述) グループ」と称する) および(6)と(7)の種群(「北海道グループ」と称する)に分けら れる。

\section{更新世における日本列島周辺の地史}

多くの日本列島産生物の分布様式の成立過程は, 日本列 
野ネズミ類から検出された寄生線虫の生物地理

島の更新世以降の地史と密接に関連することが知られるの で，まずここでは大嶋 [11］の説を中心に解説する。現在 の日本列島の基になる構造は，かなり古い時期にすでに形 成されていた。更新世 (163 万年〜 1 万年前) になると約 10 万年に一度の割合で水期が襲い, 南極大陸, ユーラシア大 陸西北部および北米大陸などの表面には大規模な水床が発 達した。そのために, 大量の水が大陸に固定されたため, 海 水面が著しく低下したことが知られる。このような現象は， 海退と呼ばれる。海退の規模は氷期によって異なり，たと えば最終水期 $(7$ 万年〜 1 万年前)では， 80 ないし $100 \mathrm{~m}$ 程 度の海面低下があったとされる。水期が終わり間水期に向 かうにつれ，気温が上昇し徐々に水床が溶け，次第に海面 も上昇した。これは海進と呼ばれるが，この現象により,こ れまで大陸の一部であった陸地が海中に完全に没する場合 や島として海洋中に残る場合が生じた。氷期に陸地であっ て，現在の本島と離島とをかつて連結していた場所が陸橋 であり，野ネズミ類はこの陸橋を経由し日本列島へ侵入を 果たした。したがって，海峡の成立した時期を知ることが， 野ネズミ類の渡来した時期を推定する上で，重要な情報の 一つとされる。

大嶋 [11]によると，今から 20 万年前の中期更新世ある いはそれ以前に宮古水道と佐渡海峡が形成され，それぞれ 沖縄本島と宮古島, 北海道と本州陸塊(現在の本州・四国・ 九州が地続きになった地域)の連なった陸地と佐渡島が分 断された。次いで，リス氷期と最終水期の間水期(約 13 万 年〜 10 万年前) に朝鮮海峡と津軽海峡が形成され，ユーラ シア大陸と本州陸塊ならびに本州陸塊と北海道が分断され た。これら両海峡は最終水期に抢ける海退でも陸化しな かった。

さらに，最終水期の終了間際， 1 万 2000 年〜 1 万年前の 間に宗谷海峡が形成され，北海道とサハリンが分断された。 また，完新世の始まったばかりの 8500 年前〜 5000 年前に 関門海峡が形成され，本州陸塊が本州，四国㧍よび九州に 分断された。国後島, 大黒島, 天売島, 壱岐扔よび能登島 などもこの時期に分断されたと推定される。

以上の上うに, 佐渡島のような歷史の古い島を除けば,多 くの島が本島と地史的に最近まで陸橋でつながっていた。 また, 最終水期の終了した約 1 万年前まで本州, 四国およ び九州は一続きの細長い島であったこと，さらに北海道は サハリンを中間に置いたユーラシア大陸からの半島地域の
先端部に位置していたことは, 今日の寄生線虫相成立を理 解する上で重要な古地理学的事実である。

\section{分布類型の解析 一特にブラキストン線に着目してー}

日本列島の地史, 当該線虫種の地理的分布域および野不 ズミ類侵入の経緯などを傍証として，ヘリグモソームム科 線虫の日本列島における分布類型の成因を解析したい。「北 海道グループ」の $H$. (P.) yamagutii, $H$. (P.) mixtum お よび $H$. neopolygyrus はいずれもユーラシア大陸の北部 から東部に分布し, 大陸での宿主は夕イリクヤチネズミ Clethrionomys rufocanus, ヒメヤチネズミC. rutilus, ヨーロッパヤチネズミC. glareolus, ハントウアカネズミ あるいはセスジネズミである。よって，このグループの線 虫類は，最終水期にサハリン経由で北海道に侵入した夕イ リクヤチネズミ，ヒメヤチネズミあるいはハントウアカネ ズミとともに分布を広げた考光られる。

「本州陸塊グループ」の $H$. ( $H$.) halli 除く2 種 $H$. $(P$.$) hasegawai, H$. protobullosus は, 現在までのところ, 日本列島以外の場所では未発見である。したがって,「北海 道グループ」の場合と異なり，その分布様式の説明は困難で ある。しかし，「本州陸塊グループ」の各祖先型が, 最終水 期以前の朝鮮海峡が陸化した時期に，八タネズミやヤチネ ズミ・スミスネズミの祖先型とともにその陸橋を渡った可 能性は非常に高い。しかし, その後開口した津軽海峡によ り北上を阻まれたかどうかは，これら野ネズミ類の化石が 北海道の地層から未発見なので不明である。しかしながら， 八タネズミ，ヤチネズミ㧍よびスミスネズミにとって，現 在の津軽海峡が分布拡大上の障壁であることは確実であ る。もちろん,これら野ネズミ類に特異的に奇生する「本州 陸塊グループ」にとっても, 津軽海峡は分布拡大上の障壁に なる。

「全日本グループ」の H. kurilensis と H. desportesi は, 日本列島以外の場所では未発見であり, 固有種である 可能性が高い。しかし，本州陸塊と北海道に分布しており， 分布様式の解析については, 前 2 グループと異なり海峡の 成立に関連した説明は困難である。

以上，自然分布をしたへリグモりームム科線虫の分布パ ターンをまとめると, Heligmosomum 属各種と Heligmosomoides 属の 2 種 $H$. protobullosus と $H$. neopolygyrus 


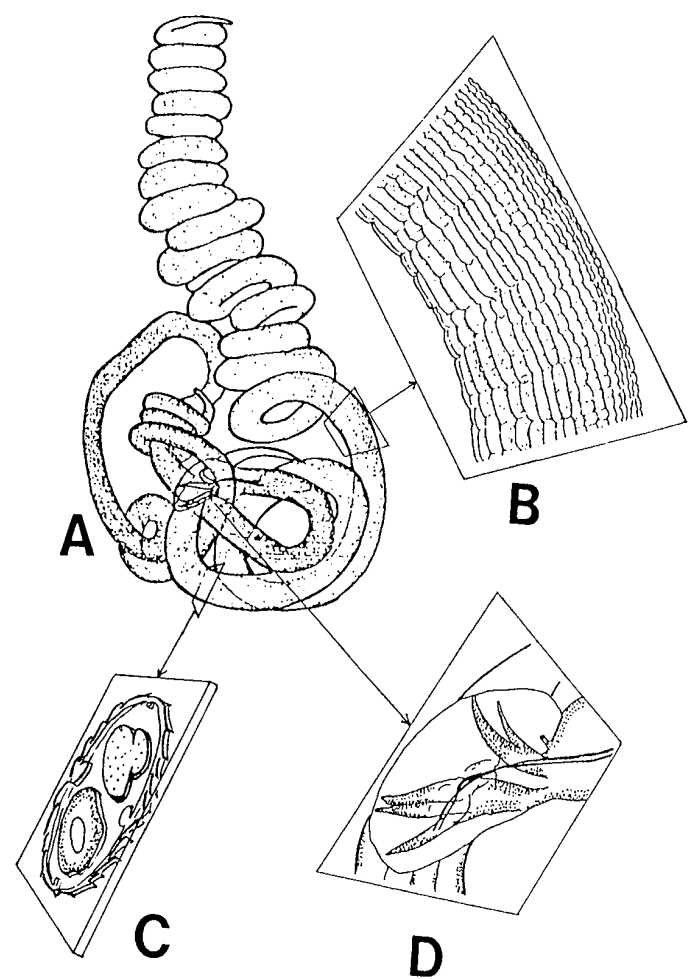

図 3 Heligmosomoides 属線虫

$\mathrm{A}$ : 交尾の様子(大きい方が雌)，B：体表上のクチクラ 隆起線, C : 虫体断面で観察された隆起線(「ギザ状のも の), D : 雄尾部の交接囊と交接刺〔A と B は Skrjabin ら [10］改写。Cと D は浅川 [5] から]

は,津軽海峡上のブラキストン線を分布境界としていた。一 方, Heligmosomoides 属の 2 種 $H$. kurilensis と $H$. desportesi ととて，ブラキストン線は分布境界となってい ないことがわかった。そこで以下では，この 2 種を含さ日 本列島産 Heligmosomoides 属の生物地理について,より詳 細に検討し，日本列島への侵入の経緯を考察したい。

\section{Heligmosomoides 属の進化 一光の 1}

日本列島産 Heligmosomoides 属の宿主一寄生体関係に は，不思議な特色が二つある。すなわち，(1)二次的な宿主 として考えられるネズミ亜科のアカネズミ属に多くの固有 種が寄生すること，(2)一方，密接な宿主一寄生体関係にあ るとされるハタネズミ亜科のヤチネズミ属およびビロード ネズミ属には, 固有の Heligmosomoides 属がいないことで ある。

つまり，もともとハタネズミ亜科で進化してきた線虫グ ループであるにもかかわらず，日本列島では最近宿主とし
て登場したネズミ亜科の方で種の多様性を示すという事実 である。なぜ，このような現象が生じたのだろうか。(2)の 不在の問題については，浅川 [5] に譲るとして，(1)のよう な種の多稼性に関する疑問を考えるには，まずこれら寄生 虫の進化の様子を知る必要がある。そこで，これまでに報 告のあった約 30 種のHeligmosomoides 属の形態学的情報 を基に系統解析を試みた。

一般に，寄生虫は自由生活をする動物と異なり，感覚器 官や運動器官は未発達であるが, その代わり生殖器官や固 着器官は非常に発達している。この傾向はHeligmosomoides 属でも同様であると考えられる。ここでは, 固 着器として体表に発達したクチクラ隆起線と, 雄の生殖器 に注目した(図 3)。雌の生殖器の形態は, 進化上保守的で細 かい系統解析の指標にはならないが，雄の交接刺や交接囊 (図 $3 \mathrm{D}$ ) の形態は非常に多様性に富んでいる。これらの進 化傾向としては，交接刺がだんだん長くなり，交接囊は小 型化あるいは左右非対称化すると推定されている。また,ク チクラ隆起線の機能は, 図 $3 \mathrm{C}$ のような虫体断面で見られ る歯車の「ギザ」のような構造が宿主の腸の粘膜に食い込 み，腸管の蠕動運動で流されないように体を固定すること である。Heligmosomoides 属と近縁の線虫グループを基に 検討した結果では，系統的に古い種群ほど，「ギザ」は大き くかつその数も少ないが,進化するにつれだんだん小さく， また数が増加する傾向にあると考えられている [4]。この 傾向は, 固着効果を保つ一方で, 腸粘膜への直接的なダメー ジを軽減するという適応的な現象と解釈されている。

これらの形態について系統解析をした結果, Heligmosomoides 属の各種は生殖器, 固着器ともに原始的な段 階にある種群 (グループIII), 生殖器は保守的で固着器が特 殊化した種群 (グループI, IIおよびV), 生殖器, 固着器 ともに進化した種群(グループIV)の三つに大別された。す なわち, Heligmosomoides 属の現生種のすべてが, 単一の 祖先種から直接分化したのではなく，原始的な祖先型を含 むグループから，まずいくつかの系統の異なるグループが 派生した後，それぞれのグループ内で種分化が進行したと 考えられる(図 4)。

\section{Heligmosomoides 属の進化 一光の 2}

それでは, 日本列島産の Heligmosomoides 属は, 系統的 にどのグループに所属するのだろうか。(1) H . desportesi 


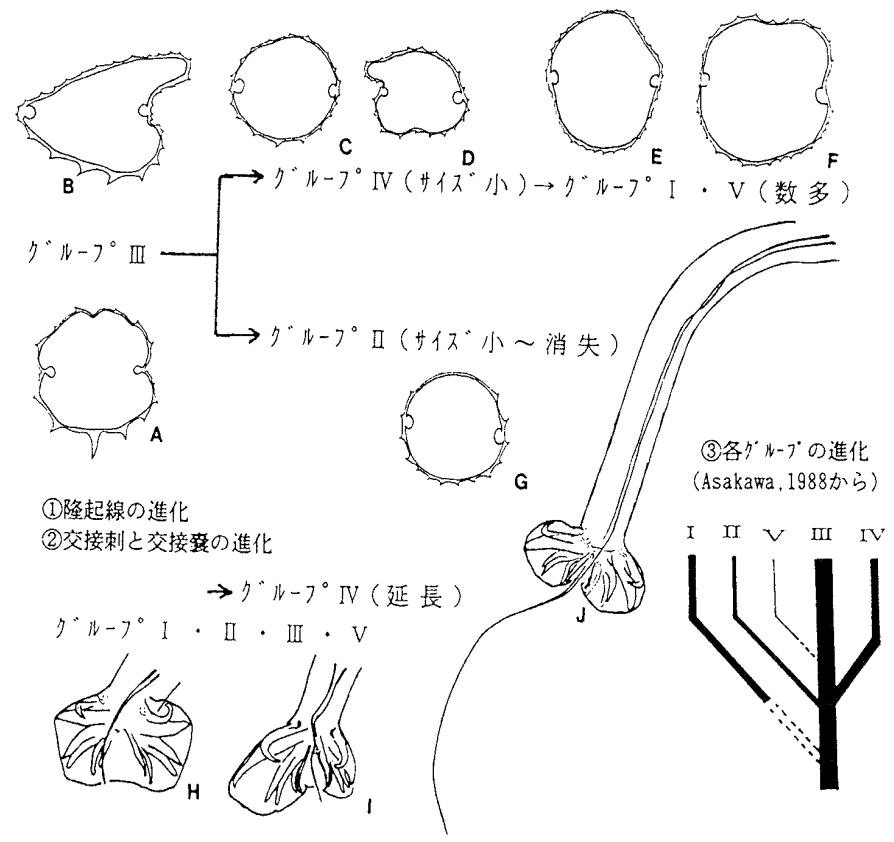

図 4 Heligmosomoides 属線虫のクチクラ隆起線と雄生殖器の 形態から見た進化

A : H. protobullosus, B と $\mathrm{H}: H$. desportesi, $\mathrm{C}: H$. montanus, D と J : H. kurilensis, $\mathrm{E}: H$. douglasi, $\mathrm{F}$ と I: $H$. neopolygyrus, $\mathrm{G}: H$. hudsoni

注：各グループ（IからV)の詳細な性質は浅川［5］を参照

は左右対称の交接囊および短い交接刺など古い夕イプの生 殖器を有す点でグループIIIに入るが，隆起線は比較的数が 多く特殊化の傾向を示す。これらのことから，H． desportesi はグループVの祖先型に近い種と考えられる。(2) $H$. neopolygyrus は右葉が大きな非対称の交接囊を持つ点と, 隆起線の数が多い点でグループ Vに入る。なお，H． neopolygyrus と非常に形態の近似する種として，(3) $H$. polygyrus がある。この種はハツカネズミの人為的掂散にと もない全世界に分布し，日本列島でも各地のハツカネズミ に普通に寄生する。時に，ハツカネズミと生息域を共有す るヒメネズミにも偶発寄生することが知られる。 $H$. polygyrus の交接囊の外背肋が $H$. neopolygyrus のものよ りも相対的に短いという派生的な形質を示すことから， $H$. polygyrus は $H$. neopolygyrus の直接的な子孫型であ ると推定される。(4) H. kurilensis は, 交接囊に特殊化は見 られないが，体長の $1 / 3$ を占める著しく長い交接刺を有す る点で, 非常に特殊化している。このタイプの交接刺を持 つ種群はグループIVであり，日本列島以外ではシベリアか ら北米にかけ7種が分布する。しかし，北米の $H$. thomomyos (後述)を除き，いずれの種もレミング属 Lemmus やハタネズミ属などのハタネズミ亜科に寄生し， $H$. kurilensis のようにネズミ亜科に寄生する例は日本列島以 外にない。(5) H. protobullosus の生殖器と隆起線は, 典型 的なグループIIIの形態学的特徵を有す。

以上のように, 日本列島産 Heligmosomoides 属 5 種は, それぞれ少しずつ異なった系統に所属することが推測され た。したがって，たとえばこれら 5 種に共通な祖先型が日 本列島にやって来て，それぞれの野ネズミ類の祖先型に宿 主転換して現生種となったとするような仮説は受け入れら れないと考えられた。

\section{古地理学と古生物学的データの援用}

そこで，前述した日本列島周辺の海峡成立史に加え，野 ネズミ類の化石の出土記録 [12］を参考に，日本列島産 Heligmosomoides 属の由来について推測を試みる(図 5)。 まず, $H$. desportesiの祖先型が，ヒメネズミの直接の祖先 型とともに，非常に古い氷期に出現した朝鮮半島あるいは それより南部に生じた陸橋を経て, 日本列島に侵入した。こ の祖先的線虫は, 当然, ・ユーラシア大陸東部にも分布して いた。しかし，グループVの直接の祖先型となる種が派生 した後, 大陸ではなんらかの原因で絶滅し，その子孫型が 日本列島に遺残したと考えられる。

次にやや時代を下り，リス氷期前後に H. protobullosus の祖先型と $H$. kurilensis の祖先型が日本列島に侵入し た。 . protobullosus の祖先型を宿した宿主は, 朝鮮半島 を経由した現生種八タネズミの直接の祖先型であったこと は確実である。しかし，H． kurilensis の祖先型を宿した宿 主が何であったかは不明である。先ほど説明したように， H． kurilensis が所属するグループVIは，北米またはュー ラシア大陸北方のハタネズミ亜科で進化した種群である。 したがって，ユーラシア大陸東南部に分布していたと推測 されるネズミ亜科のアカネズミの祖先型に, H . kurilensis の直接の祖先型が元々笴生していたとは考え難い。

ところで,北米大陸にはリス亜目のホリネズミ科(ポケッ トゴファーの類)に特異的に寄生する Heligmosomoides 属 のH. thomomyos が分布する。この線虫の起源について は，ユーラシア大陸からへベーリング陸橋を渡って北米大 陸にやってきたハタネズミ亜科の線虫が，新たにポケット ゴファーに宿主転換し，H．thomomyos が誕生したと想定 


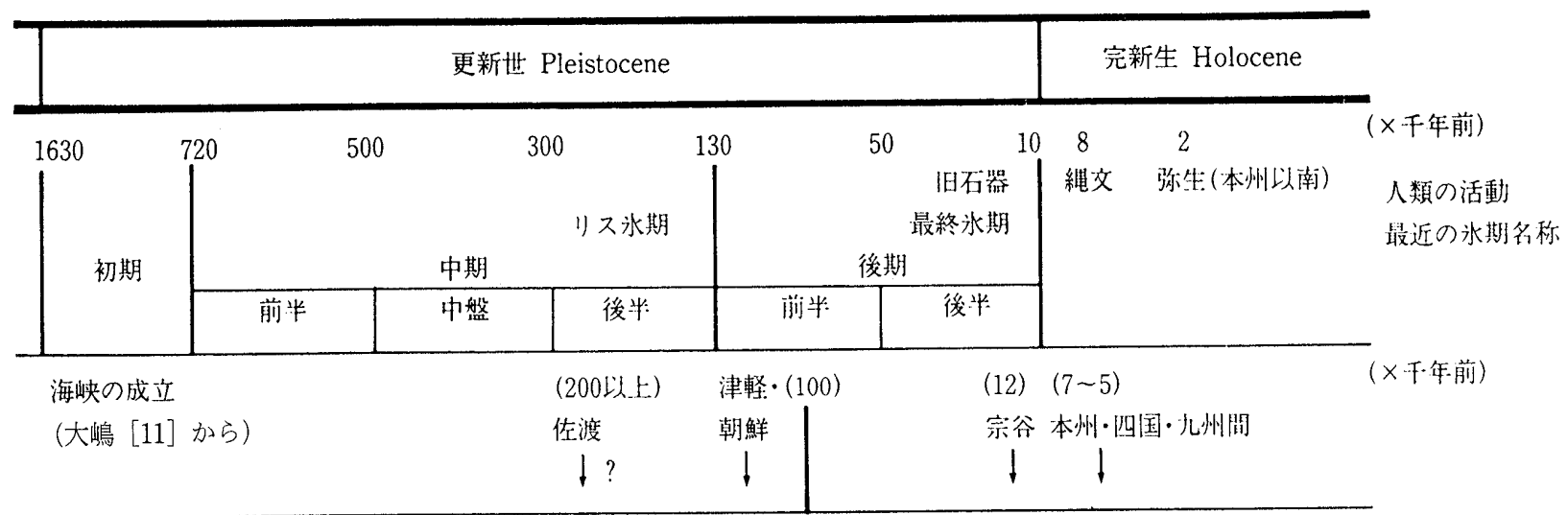

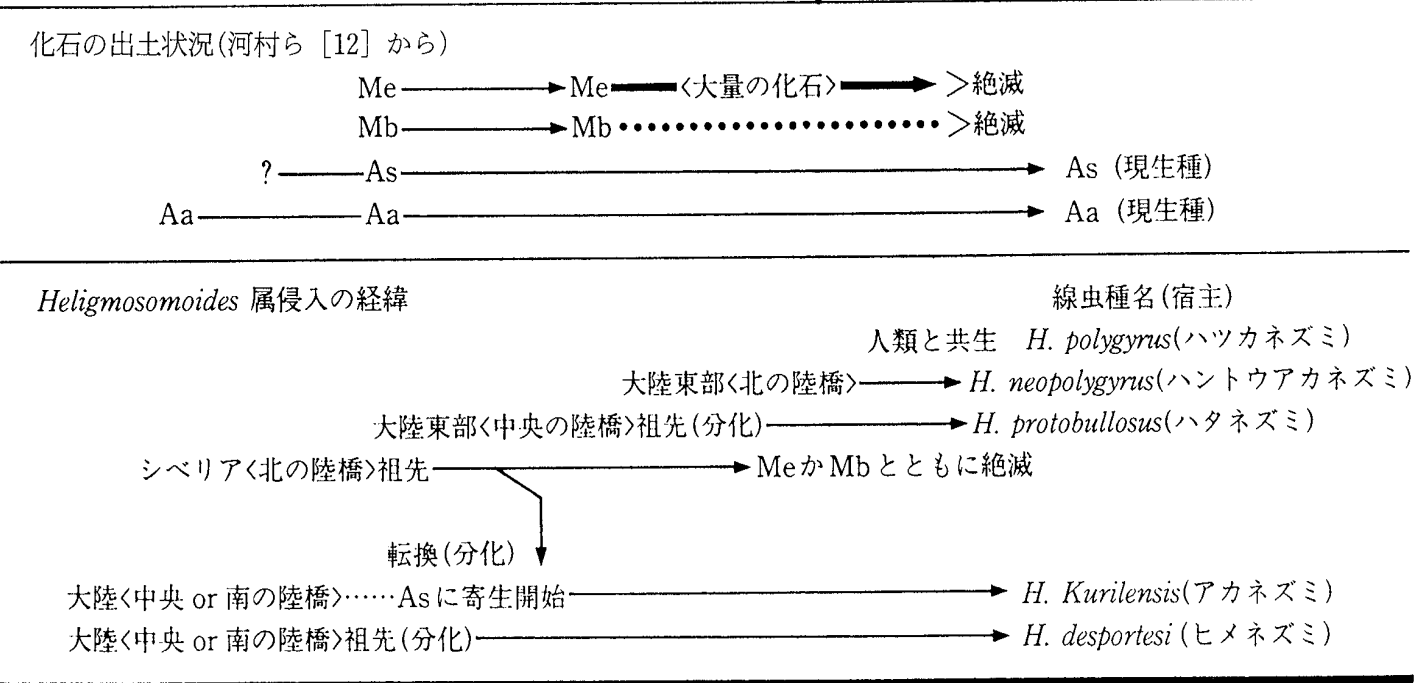

化石動物の略号 $\mathrm{Me}:$ ニホンムカシハ夕ネズミ, Mb:ブランテイオイデスハタネズミに近似の種, As: アカネズミ, Aa: ヒメネズミ。 祖先: 当㚊 Heligmosomoides 属の種の祖先型を意味する。

図 5 Heligmosomoides 属線虫の日本への侵入に関する経緯 浅川 [5] を改写

されている [13]。おそらく，H， kurilensis が種分化した 背景にもこれと似たような条件が介在し，ある種の八夕ネ ズミ巠科の寄生線虫が, アカネズミの祖先型に宿主転換し たと推測される。

しかし，H． kurilensis の祖先型を日本列島に持ち込ん 垃と考えられる動物は, 日本列島の現生種には存在しない。 ところが，更新世の日本列島各地には，北方起源の野ネズ ミ類が存在していたことが化石により知られている(図 5 の中段)。特にシベリアに起源をもち，今日では絶滅してし まったニホンムカシハタネズミ Microtus epiratticepoides とブランテイオイデスハタネズミに近似の種 $M . c f$. branditoides は, 数 10 万年前から最終水期の終った 1 万年 前まで相当な個体数が生息していたことが確認されてい
る。したがって，このような動物が日本列島に H. kurilensis の直接の祖先型を持ち込んだ後, すでに分布していたア カネズミに宿主転換した可能性がある。確かに, 化石の出 土状況によると，アカネズミとヒメネズミは更新世のかな り早い時期から日本列島に分布していたことが知られてい る。この仮説の検証は難しいが，このような説でも提出し ない限りH. kurilensis がネズミ亜科に見られることの説 明はできない。

さらに時代を下り, 最終氷期に $H$. desportesiの子孫型 から H. neopolygyrus に至る系列がユーラシア大陸の中 央部から東部で成立した後, サハリンの陸橋を経由して H. neopolygyrus がハントウアカネズミと一緒に北海道 に侵入した。しかし，すでに形成されていた津軽海峡に阻 
まれ，H．neopolygyrus は本州以南に侵入できなかった (前述)。

もしも以上の仮説が正しければ, $H$. desportesi $と H$. kurilensis は日本列島産の遺残種といえる。しかし，H． neopolygyrus はユーラシア大陸東部やサハリンにも分布 しており地理的な遺残種ではない。ただし，陸橋を経由し て自然分布した点で，これまで述べた他の Helig. mosomoides 属と同樣である。

一方, H. neopolygyrus と同じグループの H. polygyr us は，ここ数干年間に人為的に渡来したハツカネズミにと もなった，いわば寄生線虫の移入種である。現在では，人 間のいるところにはどこにでも分布する。しかし，人間か らは宿主ほどには嫌われていない。むしろ，実験寄生虫学 領域では重宝されていて，世界中の研究機関でマウスを用 い継代されている。

\section{結論}

Heligmosomoides 属について見たように，自然分布を遂 げた日本列島産野ネズミ類の寄生線虫相の成立にあたって は，日本列島の辿った地史や氷期に渡来し今日では絶滅し た動物の存在なども見逃すことができないと結論された。

生物地理学の研究には，予妨対象とする生物グループの 分類学や系統学が十分に検討されていることが必要であ る。これは寄生線虫を対象とする場合も同様である。系統 学については, 従来の形態学的な解析に加え，核酸分析な どの分子生物学的方法が開発されつつあり，精度の高い仮 説が期待される。系統学に限らず，この論文には検証すべ き問題が山積している。しかし，野山にごく普通にいる野 ネズミ類ではあるが，その寄生虫の由来には眮味深い点が 残されていることは事実である。

最後に, 寄生虫の生物地理学的研究には, どのような獣 医学的意義があるのか私見を述べたい。一つには，過去の 歴史を知ることにより，寄生虫伝播の予測という疫学的応 用につながることが考えられる。また，種々の宿主一寄生 体関係の基礎研究にもなるであろう。さらに重要な点とし ては，寄生虫学の教育上，有益な影響を与えると期待でき る。すなわち，獣医寄生虫病学の講義を受けたことのある ものなら一度は抱き，そして決して満足のできる答えが期 待されない疑問，すなわち「寄生虫は，いつ，どこからやっ て来たのか？」に対し，ある程度答えることができるのであ
る。この分野に多数の日本野生動物医学会会員が興味を抱 いて下さることを念ずる。

\section{要 約}

生物地理学的な調査研究の一環として, 日本列島産八夕 ネズミ亜科およびネズミ亜科(絜歯目：ネズミ科)の寄生線 虫相をまとめた。これまでに，ヤチネズミ属Cleth rionomys, ビロードネズミ属 Eothenomys，八タネズミ属 Microtus およU゙アカネズミ属Apodemus から記録されて いる寄生線虫類は 16 科 24 属 36 種であった。これらの内, 円虫目ヘリグモソームム科 Heligmosomoides 属について, 線虫類の種分化や地理的分布, 宿主である觢歯類の化石の 記録，日本列島の地史などを考慮にいれ，その生物地理学 的解析を試みた。

キーワード: Clethrionomys, Eothenomys Microtus, Apodemus, Heligmosomoides

\section{引用文献}

1. 白上謙一. 1972．生物学と方法一発生細胞学とはなにか。河出書房新 社, 東京.

2. Beverridge I. 1986. Coevolutionary relationships of the helminth parasites of Australian marsupials in Coevolution and systematics (Stone AR., Hawksworth DL. eds.), pp. 93-117, Clarendon Press, Oxford.

3. Brooks DR, McLennan DA. 1993. Parascript. Parasite and The Language of Evolution, Smithsonian Institution Press, Washington and London.

4. Durette-Desset MC. 1985. Trichostrongyloid nematodes and their vertebrate hosts:Reconstruction of the phylogeny of a parasitic group. Adv Parasitol 24:239-306.

5. 浅川満彦. 1995. 日本列島産野ネズミ類に見的れる寄生線虫相の生物 地理学的研究一特にヘリグモソームム科線虫の由来と変遷に着目して。 酪農学園大学紀要, 自然科学編 19:285-379

6. 高雄善則, 龟谷俊也, 米田 豊, 長谷川英男. 1990, 福岡県内の野鼠の寄 生蠕虫類について，等生虫学誌，39(增): 130

7. 王 俊秀, 後藤信男, 三浦克洋, 今井憲吉, 野口竜三, 藤田浔吉. 1975. 長 野県菅平高原に扔汁る八タネズミの内寄生虫調查(予報) I . 開嘴虫 Syngamus sp.について. 奇生虫学誌, 24(增):97.

8. Hasegawa H., Arai S., Shiraishi S. 1993. Nematodes collected from rodents on Uotsuri Island, Okinawa, Japan. J Helminthol Soc Wash 60:39-47.

9. 長谷川英男. 1990. 琉球列島の生物地理と奇生虫, 沖縄生物学誌, 28 : $1-10$.

10. Skrjabin KI, Shikhobalova NP, Shul'tz RS. 1954. [Essentials of nematology. Vol.4. Dictyocaulidae, Heligmosomatidae and Ollulanidae of animals]. Izdatz Akad Nauk SSR, Moscow (translat- 


\section{浅川 満彦}

from Russian by Israel Prog Sci Trans, 1971. Jerusalem).

11. 大嶋和雄. 1990。第四紀後期の海峡形成史. 第四紀研究 29:193-208.

12. 河村善也, 亀井節夫, 樽野博幸. 1989。 日本の中・後期更新世の哺乳動物 相. 第四紀研究 28:317-326.

13. Gardner SL, Jasmer DP. 1983. Heligmosomoides thomomyos sp. n. (Nematoda:Heligmosomidae) from pocket gophers, Thomomys spp. (Rodentia:Geomyidae), in Oregon and California. Proc Helminthol Soc Washington 50:278-284. 